\title{
Knowledge-based virtualization of human anatomy: development of an interactive atlas of the upper limbs
}

\author{
Menezes, TCF. ${ }^{1 *}$, Lorente, GD. ${ }^{1}$, Silva, LP. ${ }^{1}$, Perini, MLL. ${ }^{1}$, \\ Batigália, F. ${ }^{1}$, Fernandes, AM. ${ }^{2}$ and Padovani Júnior, JA. ${ }^{2}$
}

\author{
${ }^{1}$ Department of Anatomy, São José do Rio Preto Medical School - FAMERP, \\ Av. Brigadeiro Faria Lima, 5416, CEP 15090-000, São José do Rio Preto, SP, Brazil \\ ${ }^{2}$ Department of Otorhinolaryngology and Head and Neck Surgery, São José do Rio Preto Medical \\ School - FAMERP, Av. Brigadeiro Faria Lima, 5416, CEP 15090-000, São José do Rio Preto, SP, Brazil \\ *E-mail: tcmenezesf@hotmail.com
}

\begin{abstract}
Introduction: Currently, two types of atlas provide anatomical studies: those with two-dimensional images, and those compiled by interactive pictures; mostly drawn virtually. In recent decades, the development of virtual anatomical atlases has been encouraged and prioritized by both the technological advances and the need to facilitate and complement medical education. The aim of this study was to develop an interactive virtual atlas of the upper limbs. Material and Methods: A systematic dissection of three upper limbs (shoulder, arm, forearm and hand) of legally preserved cadavers in Anatomy Laboratory of São José do Rio Preto Medical School, SP (FAMERP) has been carried out. Results: A website has been developed to facilitate the learning of superficial and deep structures of the limbs comprising ten pictures showing the steps and the various structures and display devices (naming demarcated structures and text with relevant information about these). In addition, the website includes a photo gallery with subtitled images of the dissected upper limbs. Conclusion: In conclusion, virtual study of Anatomy by means of interactive-image display of dissected parts can facilitate and enhance the learning of the upper limbs.
\end{abstract}

Keywords: virtualization, anatomical knowledge, interactivity, virtual atlas, upper limbs.

\section{Introduction}

Scientific researches in Pedagogy indicate that Vision is the most used sensorial learning channel by mankind (BATIGÁLIA and SCIARRA, 2006). In Human Anatomy, atlases (or compendia mainly composed by figures that illustrate structures and their body relations) are essential for teaching and for learning the 7.685 terms belonging to the 11 systems of the discipline of anatomy (SOCIEDADE..., 2001). Currently, two types of atlas provide anatomical studies: one type with two-dimensional images and another one with interactive pictures which are mostly virtually drawn (FERREIRA, 1975).

Over the last few decades the building of virtual anatomical atlases has been stimulated and prioritized due to technological improvements and to the necessity of facilitating and complementing medical education (WRIGHT and HENDRICSON, 2010; McMENAMIM, 2005). This fact is signalized by the quantity of existing papers related to this subject, particularly referring to the subspecialties of Surgical Anatomy (SILVERSTEIN, DECH and KOUCHOUKOS, 2004; ST-JEAN, SADIKOT, COLLINS et al., 1998; JUANES, ESPINEL, VELASCO et al., 1996), which evoke that the most appropriate anatomical studies are the ones providing three-dimensional images or " $3 \mathrm{D}$ "-images (CHOI, TAMBLYN and STRINGER, 2008).

Even if traditional anatomists oppose this tendency as from the affirmation that virtual elements don't replace practical studies in real objects, interactive atlases are didactic instruments already potentially integrated in the current education methods in Anatomy (WRIGHT and
HENDRICSON, 2010). The employment of virtual relationship is added to the concept "Anatomy is not learned by heart, but by practice" establishing clear and reliable interactivity (McMENAMIM, 2005) and ensuring internalization of the contents (ROSSE, 1999). Such attuned relationship between student and virtual atlas is done by employing a multimedia system where the user can give commands to obtain one or more answers. In this context there are demountable figures, animation illustrating functions, analysis of anatomical variations (NOWINSKI, THIRUNAVUUKARASUU, VOLKAU et al., 2009; JOSHI, HORN and TOGA, 2009) and asynchronous virtual activities that evaluate the user's progress (FERREIRA, 1975).

On the other side there are scarce scientific papers that make images with interactive resources with focus on Upper Limb available (WRIGHT and HENDRICSON, 2010; ROSSE, 1999); frequently due to lack of a clear idea of what the method really is about (WRIGHT and HENDRICSON, 2010 ) and due to lack of knowledge of its effective potential of awaking interest in this discipline, of promoting real assimilation (ROSSE, 1999), and of creating unlimited imaging files for health professionals (FISHER, 1990).

\section{Material and Method}

A systematic dissection of three upper limbs (SANTOS, 2006) (shoulder, arm, forearm and hand) of legally preserved cadavers in the Anatomy Laboratory at São José do Rio Preto Medical School (FAMERP) has been carried out. 
The dissection comprised the following steps: incision (with scalpel handle number 4 and blade 23 ) of the skin, subcutaneous layer (adipose and membranous tissues) superficial fascia, profound fascia membrane of the muscles, intermuscular septa and neurovascular bundles (arteries, veins, nerves and lymph vessels). At each step a digital photographic register with a Sony Cyber-shot camera, Model DSC-W70, 7.2 mega pixels was made. Both the dissections and the photographic registers took place at FAMERP's Anatomy Laboratory.

The photos taken at each step of the structural stratification were treated digitally. The images have been digitalized and interactive instruments (arrows to name the displayed structures, questionnaires and answer keys to the discussed issue showing the steps of the dissection procedure) have been formulated through the PHP 5.3 program with MySQL 5.5, and after that inserted in a website.

In the final stages a web site was created which can be maintained and updated in order to enable the learning of superficial or profound structures of the referred limb.

\section{Result and Discussion}

The first stage of this project was to accomplish the dissection of the upper limbs. This process has significantly provided the necessary learning to continue the building of the virtual atlas in order to give other students and health professionals the opportunity to know and use the tool of interactivity.

Thus at the end of the project a website was created for the purpose of learning of superficial and profound structures of the referred limb with ten photos showing all the steps and the various structures and interactivity elements as well (naming the demarcated structures and inserting texts with relevant information regarding the structures). Besides this the website includes a photo gallery with subtitled images of the dissected upper limbs.

For the purpose of illustrating this paper, Figure 1 shows a page of the created website with a photo of the dissected limb. On this page the user should drag the icons with the names of the anatomical structures and drop them on the precise correspondent location. If nomenclature and structure don't fit together a red background will appear indicating error. If they fit together a green background will come up. By this means when all the structures are correctly named all backgrounds will be green lighted and a text on the right side describing every photo item will come in sight.

In the medical studies Anatomy is an utterly important branch of studies for interacting with the learning of remaining disciplines belonging to the medicine course. Besides this, Anatomy is essential during the whole medical practice, delivering the necessary knowledge for performing the physical examination in the patient, for identifying the possible pathological changes, for obtaining and for discussing a possible diagnosis (TURNEY, 2007). According to Patel and Moxham (2008) there are several methods for the anatomical studies, such as: dissection carried out by students, didactic teaching, use of anatomical models, use of slides, daily learning and the study of radiological anatomy.

Dissection became part of the medical curriculum already in the $19^{\text {th }}$ century. This method remains until now because it has been proved that the active knowledge acquisition, which involves the largest number of sense organs, is much
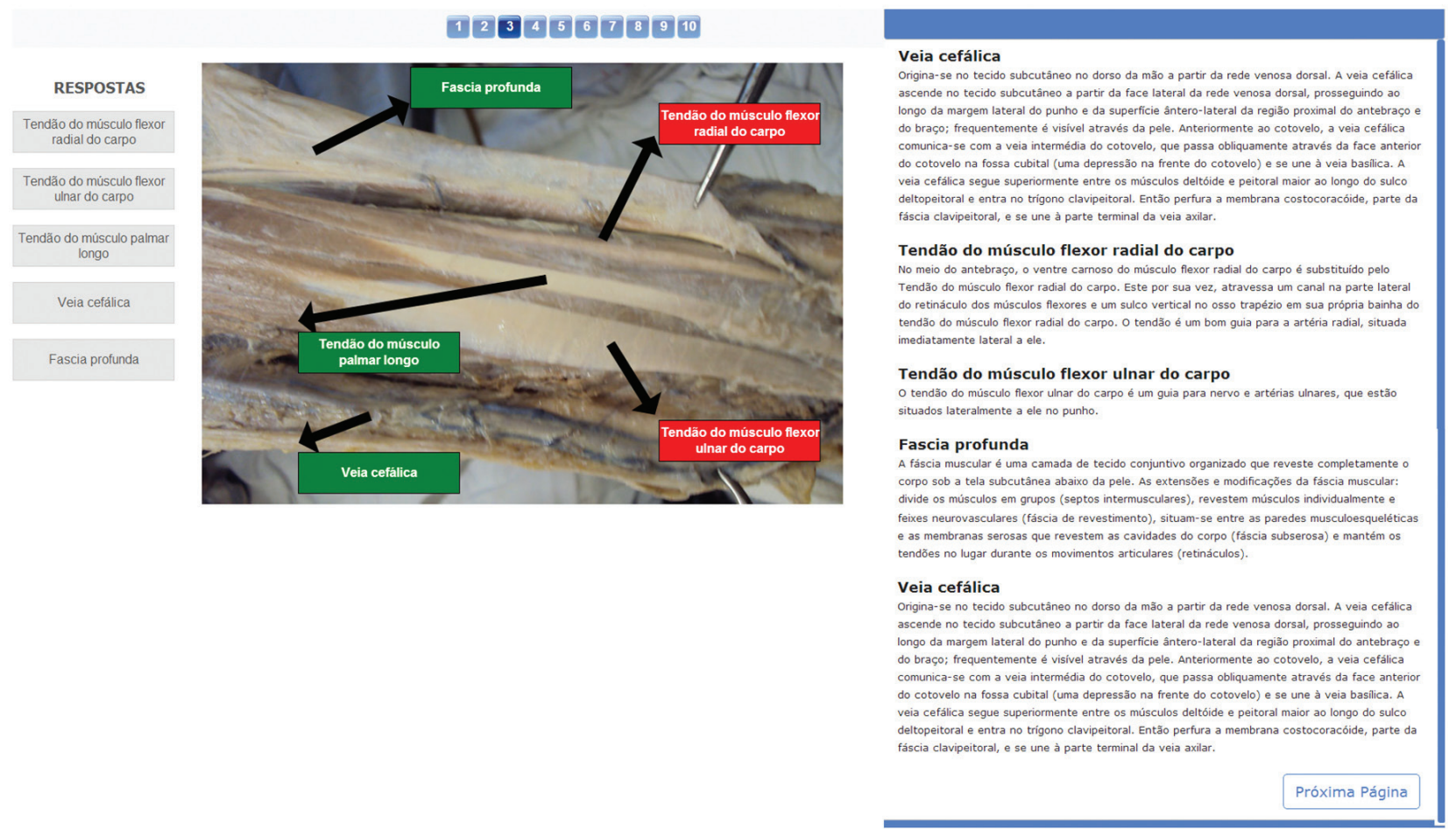

Figure 1. Page of the created website with a photo of the dissected limb. 
more effective than the passive one (KORF, WICHT, SNIPES et al., 2008).

The assimilation of anatomy through dissection can depend on several variants such as: visual skills, motivation, time dedicated to active dissection and to the study of the dissected material, cadaver integrity, dissection technics, teacher's performance, articles quality, texts, manuals and other support materials (WINKELMANN, 2007). As the quality of the dissection is deeply related to the above quoted factors, alternative technics to the classical dissection have been developed. One of these technics consists in the development of virtual programs such as the VHD (The Virtual Human Dissector) which aims the learning of Anatomy and the development of clinical skills (DONNELLY, PATTEN, WHITE et al., 2009).

In the study "Virtual human dissector as a learning tool for studying cross-sectional anatomy" the teaching of Anatomy through the traditional method has been compared with the teaching using the VHD program, and it has been concluded that both methods are equally effective. However, the virtual method can avoid some hindrances such as shortage of cadavers, difficulty of some students to deal with anatomical pieces and teacher's inadequate skills to teach this content.

Another alternative methodology discussed by Turmezei, Tam and Loughna (2009) involved the digitizing of normal radiological images creating a digital library as an adjunct method of classical dissection. In this way this program has created new opportunities and technics of handling, rebuilding and reforming 3D radiological images, contributing to consolidation of knowledge.

Any method that stimulates the interest in Anatomy should be put forward and extolled. In this way, even if some anatomists show resistance (WRIGHT and HENDRICSON, 2010), new analyses and perspectives about different ways of studying need to be created and included in the medical education (WINKELMANN, 2007).

\section{Conclusion}

The virtual study of Anatomy showing interactive images of dissected pieces can facilitate and solidify the learning of the upper limb by granting familiarization with the anatomical structures, by facilitating memorization through the interactivity and by showing knowledge of the anatomical variations in the upper limb.

Acknowledgements: The authors thank the research financial source BIC (Scholarship for Scientific Initiation - Bolsa de Iniciação Científica) of São José do Rio Preto Medical School - FAMERP and the computer programmer Thiago Colebrusco as well, who enabled the accomplishment of this project.

\section{References}

BATIGÁLIA, F. and SCIARRA, AMP. Philosophical Techniques for the Learning of Anatomy. Plexus - Newsletter of the International Federation of Associations of Anatomists, 2006, p. 6-7.

CHOI, AR., TAMBLYN, R. and STRINGER, MD. Electronic resources for surgical anatomy. ANZ Journal of Surgery, 2008, vol. 78, n. 2, p. 1082-1091. PMid:19087047.
DONNELly, L., PATTEN, D., WHITE, P. and FINN, G. Virtual human dissector as a learning tool for studying cross-sectional anatomy. Medical Teacher, 2009, vol. 31, n. 6, p. 553-555. PMid:19288305. http://dx.doi.org/10.1080/01421590802512953

FERREIRA, BH. Aurelio. Novo Dicionário da Língua Portuguesa. 1975. p. 156-774.

FISHER, WS 3rd. Computer-aided intelligence: application of an expert system to brachial plexus injuries. Neurosurgery, 1990, vol. 27, n. 5, p. 837-843. PMid:2259420. http://dx.doi. org/10.1227/00006123-199011000-00029

JOSHI, SH., HORN, JD. and TOGA, AW. Interactive exploration of neuroanatomical meta-spaces. Frontiers in Neuroinformatics, 2009, vol. 3, p. 38. PMid:19915734 PMCid:PMC2776489. http:// dx.doi.org/10.3389/neuro.11.038.2009

JUANES, JA., ESPINEL, JL., VELASCO, MJ., ZOREDA, JL., RIESCO, JM., CARMENA, JJ., BLANCO, E., MARCOS, J. and VAZQUEZ, R. A three-dimensional virtual model of the head generated from digitalized CT or MR images for anatomical-radiological and neurosurgical evaluations. Journal of Neuroradiology, 1996, vol. 23, n. 4, p. 211-216. PMid:9107107.

KORF, HW., WICHT, H., SNIPES, RL., TIMMERMANS, JP., PAULSEN, F., RUNE, G. and VOGT, EB. The dissection coursenecessary and indispensable for teaching anatomy to medical students. Annals of Anatomy, 2008, vol. 190, n. 1, p. 16-22. PMid:18342138. http://dx.doi.org/10.1016/j.anat.2007.10.001

McMENAMIM, PG. A simple interactive teaching aid for medical undergraduates studying the brachial plexus. Medical Teacher, 2005, vol. 27, n. 2, p. 169-171. PMid:16019340. http://dx.doi. org/10.1080/01421590400029491

NOWINSKI, WL., THIRUNAVUUKARASUU, A., VOLKAU, I., MARCHENKO, Y., AMINAH, B., PUSPITASARI, F. and RUNGE, VM. A three-dimensional interactive atlas of cerebral arterial variants. Neuroinformatics, 2009 , vol. 7, n. 4, p. 255-264. PMid:19957055. http://dx.doi.org/10.1007/s12021-0099055-0

PATEL, KM. and MOXHAM, BJ. The Relationships Between Learning Outcomes and Methods of Teaching Anatomy as Perceived by Professional Anatomists. Clinical Anatomy, 2008, vol. 21, n. 2, p. 182-189. PMid:18189277. http://dx.doi.org/10.1002/ ca. 20584

ROSSE, C. Anatomy atlases. Clinical Anatomy, 1999, vol. 12, n. 4, p. 293-299. http://dx.doi.org/10.1002/(SICI)10982353(1999)12:4<293::AID-CAl3>3.0.CO $2-4$

SANTOS, CAS. Frequência de veia braquial comum em cadáveres humanos: Estudo Anatômico. 2006.

SILVERSTEIN, JC., DECH, F. and KOUCHOUKOS, PL. Enhancing radiological volumes with symbolic anatomy using image fusion and collaborative virtual reality. Studies in Healthy Technology and Informatics, 2004, vol. 98, p. 347-352. PMid:15544303.

Sociedade Brasileira de Anatomia. Terminologia Anatômica. São Paulo: Manole, 2001. p. 1-10.

ST-JEAN, P., SADIKOT, AF., COLLINS, L., CLONDA, D., KASRAI, R., EVANS, AC. and PETERS, TM. Automated atlas integration and interactive three-dimensional visualization tools for planning and guidance in functional neurosurgery. IEEE Transactions on Medical Imaging, 1998, vol. 17, n. 5, p. 672-680. PMid:9874291. http://dx.doi.org/10.1109/42.736017

TURMEZEI, TD., TAM, MDBS. and LOUGHNA, S. A survey of medical students on the impact of a new digital imaging library in dissection room. Clinical Anatomy, 2009, vol. 22, n. 6, p. 761-769. PMid:19637297. http://dx.doi.org/10.1002/ca.20833 
TURNEY, BW. Anatomy in a modern medical curriculum. Annals of the Royal College of Surgeons of England, 2007, vol. 89, n. 2, p. 104-107. PMid:17346399 PMCid:PMC1964553. http:// dx.doi.org/10.1308/003588407X168244

WINKELMANN, A. Anatomical dissection as a teaching method in medical school: a review of the evidence. Medical Education, 2007, vol. 41, n. 1, p. 15-22. PMid:17209888. http://dx.doi. org/10.1111/j.1365-2929.2006.02625.x
WRIGHT, EF. and HENDRICSON, WD. Evaluation of a 3-D interactive tooth atlas by dental students in dental anatomy and endodontic courses. Journal of Dental Education, 2010, vol. 74, n. 2, p. 110-122. PMid:20145066. www.cameraversuscamera.com. br/cameras/sw70/ck_sw70.html, accessed on May, 18th 2011.

Received June 20, 2013 Accepted March 16, 2014 